\title{
"The role of the banking system in supporting the financial equilibrium of the enterprises: the case of Ukraine"
}

\begin{tabular}{|c|c|}
\hline \multirow{7}{*}{ AUTHORS } & Svitlana Yehorycheva (D http://orcid.org/0000-0002-7829-7073 \\
\hline & R https://publons.com/researcher/2119494/svitlana-b-yehorycheva/ \\
\hline & Tetiana Gudz ID http://orcid.org/0000-0002-2310-5425 \\
\hline & Mykhailo Krupka iD http://orcid.org/0000-0002-8775-1397 \\
\hline & Oleh Kolodiziev (D http://orcid.org/0000-0002-6715-2901 \\
\hline & R http://www.researcherid.com/rid/C-6094-2018 \\
\hline & Nataliia Tarasevych (D http://orcid.org/0000-0002-2110-7320 \\
\hline ARTICLE INFO & $\begin{array}{l}\text { Svitlana Yehorycheva, Tetiana Gudz, Mykhailo Krupka, Oleh Kolodiziev and } \\
\text { Nataliia Tarasevych (2019). The role of the banking system in supporting the } \\
\text { financial equilibrium of the enterprises: the case of Ukraine. Banks and Bank } \\
\text { Systems, 14(2), 190-202. doi:10.21511/bbs.14(2).2019.17 }\end{array}$ \\
\hline DOI & http://dx.doi.org/10.21511/bbs.14(2).2019.17 \\
\hline RELEASED ON & Monday, 08 July 2019 \\
\hline RECEIVED ON & Friday, 31 May 2019 \\
\hline \multirow[t]{2}{*}{ ACCEPTED ON } & Wednesday, 03 July 2019 \\
\hline & $(\mathrm{cc})$ EY \\
\hline LICENSE & $\begin{array}{l}\text { This work is licensed under a Creative Commons Attribution } 4.0 \text { International } \\
\text { License }\end{array}$ \\
\hline JOURNAL & "Banks and Bank Systems" \\
\hline ISSN PRINT & $1816-7403$ \\
\hline ISSN ONLINE & $1991-7074$ \\
\hline PUBLISHER & LLC "Consulting Publishing Company "Business Perspectives" \\
\hline FOUNDER & LLC "Consulting Publishing Company "Business Perspectives" \\
\hline
\end{tabular}

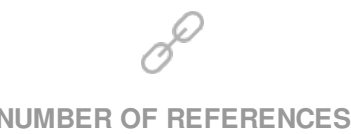

26

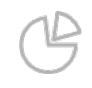

NUMBER OF FIGURES

5

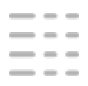

NUMBER OF TABLES

3

(C) The author(s) 2022. This publication is an open access article. 


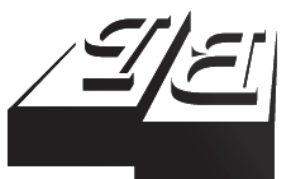

BUSINESS PERSPECTIVES

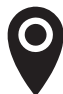

LLC "CPC "Business Perspectives" Hryhorii Skovoroda lane, 10, Sumy, 40022, Ukraine

www.businessperspectives.org

Received on: $31^{\text {st }}$ of May, 2019 Accepted on: $3^{\text {rd }}$ of July, 2019

(c) Svitlana Yehorycheva, Tetiana Gudz, Mykhailo Krupka, Oleh Kolodiziev, Nataliia Tarasevych, 2019

Svitlana Yehorycheva, Doctor of Economics, Professor, Department of Management, Institute for Personal Training of the State Employment Service of Ukraine, Ukraine.

Tetiana Gudz, Ph.D. in Economics, Associate Professor, Department of Finance and Banking, Poltava University of Economics and Trade, Ukraine.

Mykhailo Krupka, Doctor of Economics, Professor, Department of Finance, Money Circulation and Credit, Ivan Franko National University of Lviv, Ukraine.

Oleh Kolodiziev, Doctor of Economics, Professor, Head of the Department of Banking, Simon Kuznets Kharkiv National University of Economics, Ukraine.

Nataliia Tarasevych, Ph.D., Associate Professor, Department of Banking, Odessa National Economic

University, Ukraine.

\section{(ㄷ)(ㄱ)}

This is an Open Access article, distributed under the terms of the Creative Commons Attribution 4.0 International license, which permits unrestricted re-use, distribution, and reproduction in any medium, provided the original work is properly cited.
Svitlana Yehorycheva (Ukraine), Tetiana Gudz (Ukraine), Mykhailo Krupka (Ukraine), Oleh Kolodiziev (Ukraine), Nataliia Tarasevych (Ukraine)

\section{THE ROLE OF THE BANKING SYSTEM IN SUPPORTING THE FINANCIAL EQUILIBRIUM OF THE ENTERPRISES: THE CASE OF UKRAINE}

\begin{abstract}
The financial equilibrium ("financial health") of the enterprises is a prerequisite for their sustainable development, which ensures macroeconomic stability of the economy and the welfare of the state. It should be supported by the banking system, which performs the function of the effective reallocation of capital. Recently, the Ukrainian banking system itself is in a challenging situation and is undergoing a period of transformation. The purpose of the study is to assess how sufficiently the banking system of Ukraine supports the financial equilibrium of enterprises and to find the possibilities to strengthen its role in the progress of the real sector of economy. The authors single out three stages of financial equilibrium growth; each of them can be supported by the relevant banking services. The empirical analysis proves that the Ukrainian banks successfully ensure only the first stage, namely, liquidity balancing. To quantitatively assess the role of the banking system in supporting the enterprises' financial equilibrium, a multivariate regression applying mathematical gnostic analysis in the program shell $\mathrm{R}$ Console is used. The research makes it possible to find out that only the economy monetization, the share of time deposits of economic entities and growth rate of mortgage loans have a positive effect. The authors conclude that the problems of both enterprises and the banking system are in the sphere of development and implementation of government economic policy and are aggravated by the restrictive monetary policy.
\end{abstract}

Keywords

banking system, corporate finance, financial equilibrium, banking services, lending, interest rates, monetary policy

JEL Classification E52, G21, G30

\section{INTRODUCTION}

The Ukrainian economy now faces many challenges of current and strategic development: overcoming the remote consequences of the deep 2014-2015 recession, ensuring acceleration of the GDP growth, creating environment for public debt reduction, deep restructuring and modernization of the innovative basis, etc. Only financially strong and economically stable business entities in rather favorable external environment are able to realize these ambitious and at the same time, vital tasks to preserve an independent state.

Along with the institutional factors that play an extremely important role in implementing economic reforms in emerging market countries, the banking system should have a serious positive impact on the real economy. Its development, the innovative improvement of products and services, as well as the monetary effects of its performance should help to strengthen and balance corporate finance. The role of the banking system in a transformational economy is determined pre- 
cisely by the extent to which it serves as a source of funds for the real sector. The growing separation of the bank capital from the productive sphere increases the uncertainty of long-term economic prospects, the likelihood of deploying new financial crisis, restricts investment, and finally adversely affects the financial equilibrium of economic entities, which is the basis of ensuring the equilibrium of the national economy.

\section{LITERATURE REVIEW}

The financial equilibrium of enterprises is a rather new issue for Ukrainian economic science, although foreign scholars have been widely examining it through economic modeling enterprises' "financial health" as an opposite to bankruptcy. Altman and Fleur (1981) were one of the first to make mathematical model of the turning point in the financial position of the firm which threatens bankruptcy. Dhaliwal, Li, and Xie (2010) research the relationship between the financial health of corporations and the benefits of institutional investors in the choice of financial instruments for investment. The authors define the positive influence of institutional investors on corporate finance. It has also been proven that the value of institutional investors' capital is a function of the financial health of corporations.

Belolipetskii (2000) proves that the equilibrium in corporate finance causes a financial equilibrium throughout the national economy taking into consideration the same key financial conflict set for the enterprise: between yield, liquidity and risk. Kostyrko (2008) argues that financial equilibrium is the basis for an integrated estimation of the enterprise's financial position. Lvova (2019) examines three key theoretical foundations for corporate financial health assessment: bankruptcy prediction, investment analysis and financial systems assessment. Gudz (2018) proposes the broad concept of financial equilibrium considering its levels, the role in corporate finance, the types of financial equilibrium, the stages of its growth, and management methods.

When examining external factors ensuring the financial equilibrium of business entities, the researchers focus on the performance of the banking system, the situation on financial markets, and the nature of the monetary policy of the central bank. In the mid-1980s, Bernanke and Gertler (1985) questioned the validity of ModiglianiMiller's theorem on the fact that economic deci- sions do not depend on the financial structure and the addition of financial intermediaries to this environment has no consequences for real activity. They argue that financial intermediaries (in particular, banks) provide important real services to the economy and that these services have substantive implications for the behavior of economic entities. The constant business relations between banks and companies were shaped in the concept of "relationship banking", which had been analyzed by Besanko and Thakor (1993) in the context of portfolio choices of banks and borrowers' well-being and by Boot (2000) regarding its origin, scope, and benefits for all parties.

Davis (1994) argues that, in terms of asymmetry of information and incomplete contracts, bank financing is preferred to maintain a balance of corporate finances than bond financing, especially for small firms. There is direct evidence that bank relationships reduce investment and financial constraints on liquidity and may improve overall performance. Schnitzer (1999) proves that banks play a central role in financing and monitoring firms in transition economies, due to poorly developed capital markets, a lack of accumulated profits for internal financing, and a dominance of strongly insider-controlled firms.

Sufi (2005), in his Ph.D. dissertation, examines the importance of commercial banks in financing decisions of corporations. Inter alia, he analyses the use of credit lines. The results suggest that lines of credit provide bank-managed flexibility for the firms, which are able to obtain them. The firms use lines of credit as the incremental source of adjustments in leverage ratios and nominal levels of debt. Bolton and Freixas (2006) indicate the impact of the monetary policy transmission effects on the composition of the firm's financing. Savchenko (2011) defines the mechanism of influence of the banking system on the economic equilibrium. $\mathrm{He}$ characterizes it as a set of elements that transform the impulses generated by the banking system. 
The author notes that both macro- and microeconomic systems (including enterprises) can be the recipients of this influence and their equilibrium depends on such impulses. Kovalenko (2013) considers the economic essence of financial and credit interaction between banks and enterprises, emphasizing the conditions for ensuring the efficiency of such interaction and its impact on the financial position of business entities. Similar problems are raised in the study by Neizvestna (2016). Banks' assistance in enterprises' investments as a basis for their steady and balanced development is analyzed by Bilenko (2015) using the countries of Central and Eastern Europe as an example.

\section{RESULTS AND DISCUSSION}

It is well-known that the high level of production, which is ensured by financially stable economic entities, is the basis of the nation's welfare. According to the authors, financial equilibrium is one of the most important characteristics of the financial performance of the enterprises.

\subsection{The essence of financial equilibrium of enterprises as a subject to the banking system's influence}

The financial equilibrium can be defined as balancing the processes of formation of the enterprise's financial position depending on their intensity, direction of change, the nature of internal interaction, and the sensitivity to the influence of external factors (Gudz, 2018). The role of financial equilibrium is to ensure the viability and sustainability of corporate finance. Liquidity, solven$c y$, and financial stability can be considered as its forms, and financial potential balanced with the needs of sustained development is its material embodiment.

The enterprises' financial equilibrium as an economic phenomenon relates to the system of economic relations. It is one of the key points in the process of national economy development. After all, financial equilibrium enterprises are guarantors of price stability and competitiveness of the economy, promising employers, powerful budget sources, and active and efficient consumers of financial services. Therefore, due to the ensuring the financial equilibrium of economic entities it becomes possible to create favorable environment for the development of an economically powerful state with the prospect of its transformation into a state of social equilibrium.

It is obvious that the problem of supporting the financial equilibrium of the economic entities as the basis for economic progress should be solved not only by the financial management of the enterprises themselves, not only by the favorable institutional environment for their activity (competition protection, tax system, amortization policy, customs regulation, exchange rate regime, the nature of monetary policy, etc.), but also by the national banking system. The dialectic unity of the real and financial sectors of the economy stems from the fact that they must mutually create the conditions for their stable performance and development. And if the financial sector is able to grow, breaking away from the real one due to a speculative component, then the development of production is extremely complicated without the participation of banks. The latter, as it was proved by J. Schumpeter in the early 20 th century, provide funding to create "new combinations", that is innovations that ensure progress.

The financial equilibrium is a dynamic phenomenon that undergoes certain stages from the lower, basic forms, which are the basis of survival of the enterprise, to the highest, which constitute countercyclical anti-bankruptcy buffer and financial potential for its stable development. The implementation of each of these stages can be supported by certain banking services or by the creation of the possibilities to implement financial decisions (Figure 1). This can take place most effectively within the framework of the concept of "relationship banking" that means: “... the establishment of a long-term relationship between a bank and its customers. The main advantage is that it enables the bank to develop in-depth knowledge of a customer's business, which improves its ability to make informed decisions regarding loans and other services to the company. The latter expects to benefit by increased support during difficult times" (Law, 2018). 


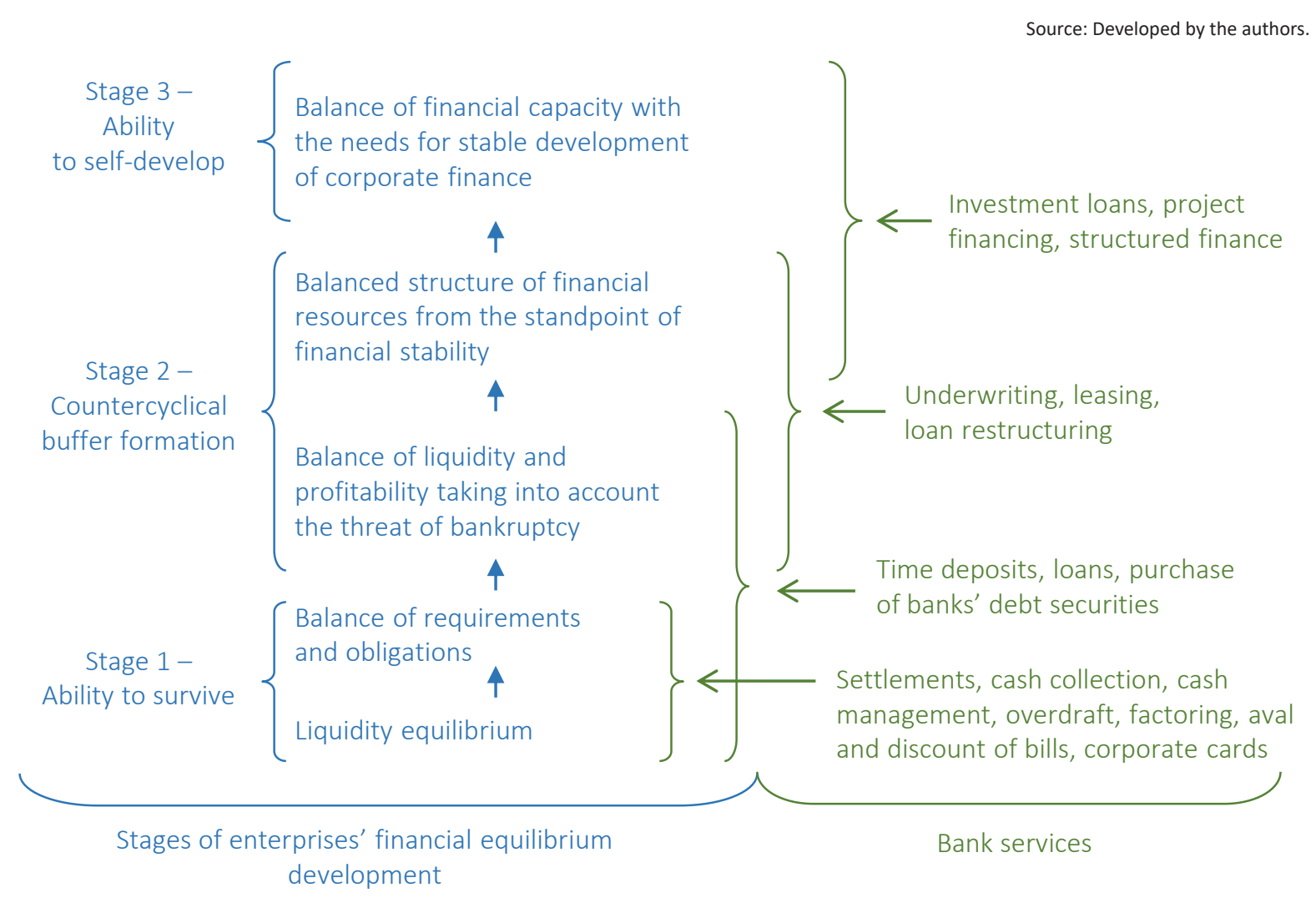

Figure 1. The stages of financial equilibrium growth and appropriate banking services

\subsection{Banking services in ensuring the corporate finance equilibrium}

The first stage in the formation of the financial equilibrium of an enterprise presupposes establishing liquidity equilibrium, which is the basis for ensuring its stable solvency. It is based on a rational asset structure, timing of incoming and outgoing cash flows, timeliness and completeness of settlements with debtors and lenders, as well as a balanced structure of requirements and obligations. It is difficult to overestimate the role of banks in this case because payment intermediation is one of their basic functions. The velocity of money, the ability of economic entities to forecast and manage their cash flows, and the turnover of their funds depend on how efficiently payment systems operate in the country.

Established in Ukraine in 1993, the nationwide payment system of RTGS class - System of Electronic Payments (SEP) currently provides 97\% of interbank transfers in the national currency. Already since its origination, the SEP, performing interbank transfers in the file (or batch) mode, ensured the receiving the transfer in no more than two hours. Such time was much shorter comparing with the system of postal or telegraph letters of advice existing in the USSR, as well as with payment processing time (up to three days) in clearing systems of many developed countries. Currently, the SEP fulfils payments in the file mode in 1520 minutes; in addition, since 2001 it has become possible to make payments in real time, with the immediate transfer of funds to the payee's account. In 2018, the system processed 357.0 million payments amounting to UAH 25.0 trillion. $91 \%$ of these payments were originated from customer accounts, and $90 \%$ of them were initiated from current accounts of business entities (National Bank of Ukraine, 2019a). Consequently, the latter are the most active users of the SEP services.

During the last decade, Ukrainian banks have been actively developing channels for remote access to client accounts by implementing innovative information technologies. In the early 2010s, based on the analysis of the 60 most powerful banks belonging to the I-III groups according to the National bank of Ukraine (NBU) classification (by assets), it was found out that the "Client- 
Bank" system was offered by all the largest banks (17 institutions). But in the other groups (22 and 21 banks), there were only $76 \%$ of such institutions. As to Internet banking for legal entities, these indicators were respectively $68.8 \%, 58.8 \%$, and $42.9 \%$, and the mobile banking $-75 \%$, 53\%, and 5\%, respectively (Yehorycheva, 2012). Currently, the "Client-Bank" and "Internet-Client-Bank" services are offered by all Ukrainian banks, even the smallest or recently registered ones. Mobile applications are in the spectrum of services of at least one third of banks.

However, nowadays, it is not enough for enterprises to have only timely and prompt settlements. The progress of payment technologies should be combined with bank's assistance in managing cash flows and balances on accounts in order to optimize them. All these aspects are included in the service of cash management, which is intended for large corporate clients, in particular, holding companies. This service, innovative for Ukraine, has been adopted from foreign markets. It is complex, high-tech, needs the high level of personnel qualification and customer awareness. Therefore, not even all banks of foreign banking groups propose it: Alfa-Bank, Raiffeisen Bank Aval, OTP Bank, Ukrsibbank, Prominvestbank, ING Bank and several others. Cash management ensures the effective use of time lags between receipt and use of funds, managing the client's credit position, forecasting financial flows, etc. This service includes the following components: consolidated statement, headquoting, cash pooling, and zero balancing.

In addition, competently organized cash management makes it possible to use effectively overdraft as a product to maintain liquidity. This type of short-term financing is actively used by enterprises to cover the time gap between incoming and outgoing cash flows. Its main advantage is that all funds received on the client's account are directed to pay off the debt, which allows for saving on interest payments. The nature of these operations does not allow to determine the real amounts of such loans according to available statistics of current accounts' turnover. Some idea of the dynamics of lending in the form of overdraft can be obtained by its share in the total amount of loans provided by banks to economic entities. For the period 1998-2007, this share increased from $0.5 \%$ to $3.5 \%$ (National Bank of Ukraine, 2019b), and at the beginning of 2019 it was $2.3 \%$ (National Bank of Ukraine, 2019c).

Factoring financing is a vital prerequisite for ensuring financial stability and economic growth for the companies that supply goods on terms of delayed payment. It solves the problem of working capital deficit for a supplier, and this occurs without increasing its payables. Other advantages of factoring financing are that it is granted for the period of actual delay of payment, does not require the pledging of collateral and may increase together with the sales volume of the enterprise.

In Ukraine, classic factoring was offered to clients for the first time in 2001 by Ukrsotsbank. Being rather complex, this service is provided nowadays by only 20-25 banks (of the total number about 80 ) and the amount of purchased factoring claims constitutes less than one percent of the loan portfolio of the banking system. Moreover, the banking factoring market is highly concentrated, as of January 1, 2018, almost $60 \%$ of the total amount of financing (UAH 2,936.0 million) was provided by three banks: Ukreximbank, FUIB and Tascombank (National Bank of Ukraine, 2019c). Under the terms offered by banks, financing is carried out in the amount of 80 to $95 \%$ of the volume of supplies, the delay of payment is up to $90-180$ days, the service of electronic factoring is offered. It is important that some banks offer a new type of factoring for Ukraine - without regress, when the risk of non-payment by the client's debtors is completely transferred to the factor.

Discounting of bills plays the same role as factoring financing in achieving the financial equilibrium of enterprises. However, because of the lack of traditional use of bills in Ukrainian economy, this service is not in demand. It is offered by few banks with the share in credit portfolio of less than $0.01 \%$ (National Bank of Ukraine, 2019c).

Leasing services are extremely attractive for businesses, especially for small and medium-sized ones, which are not always creditworthy in the classical sense. Leasing as a method of updating fixed assets does not require significant one-time expenses; it allows quickly switching to a new technological base and constantly improving it. In this case, 
there is no withdrawal of own funds, the relevant assets and liabilities are balanced by amounts and terms, the enterprise is given the opportunity to reduce tax payments. All of this positively affects the financial equilibrium of enterprises, ensuring the creation of a countercyclical buffer. However, currently only 20-25 banks provide leasing services in Ukraine. The total volume of these operations as of January 1, 2018 amounted to UAH 17.6 billion, which was about $4 \%$ of the loan portfolio. The banking leasing market is extremely concentrated, since more than $75 \%$ of its amount is constituted by Privatbank's transactions.

Of course, one of the main sources of enterprises' fund replenishment is bank lending, which is aimed to ensure development and innovation, to increase the profitability of equity capital due to the effect of the financial leverage, thereby maintaining a financial equilibrium. Ukrainian banks provide economic entities with one-time loans and credit lines, loans for working capital replenishing and investment, for the specific needs of certain sectors of the economy, in particular, agribusiness and SMEs.

Analyzing official statistics (Figure 2), it should be noted that the absolute amounts of lending to business entities are slightly increasing; howev- er, given the reduction of the official hryvnia exchange rate and inflation trends, starting from 2014, they are decreasing. This is reflected in the decrease in the rate of lending penetration (ratio of loans to GDP), which in 2017 reached the minimum in the last 10 years. In terms of ensuring the financial equilibrium of industrial enterprises as a basis for economic development, the structure of the bank's loan portfolio by type of economic activity is unsatisfactory: one third of loans are directed to the trade, which is largely focused on the sale of imported goods, and only a quarter of loans - to the manufacturing.

At the same time, the share of long-term loans in their total amount is gradually increasing in recent years, which is generally a positive trend. However, the own funds of enterprises remain the main source of investment, ten times exceeding the share of bank loans (State Statistics Service of Ukraine, 2019).

Finally, the bank time deposits play a significant role in balancing liquidity and profitability of economic entities. Ukrainian banks offer deposits to business entities from a few days to two years or more. The latter are often used as a collateral for a loan. The amount of time deposits of business entities over the past ten years has increased 3.5

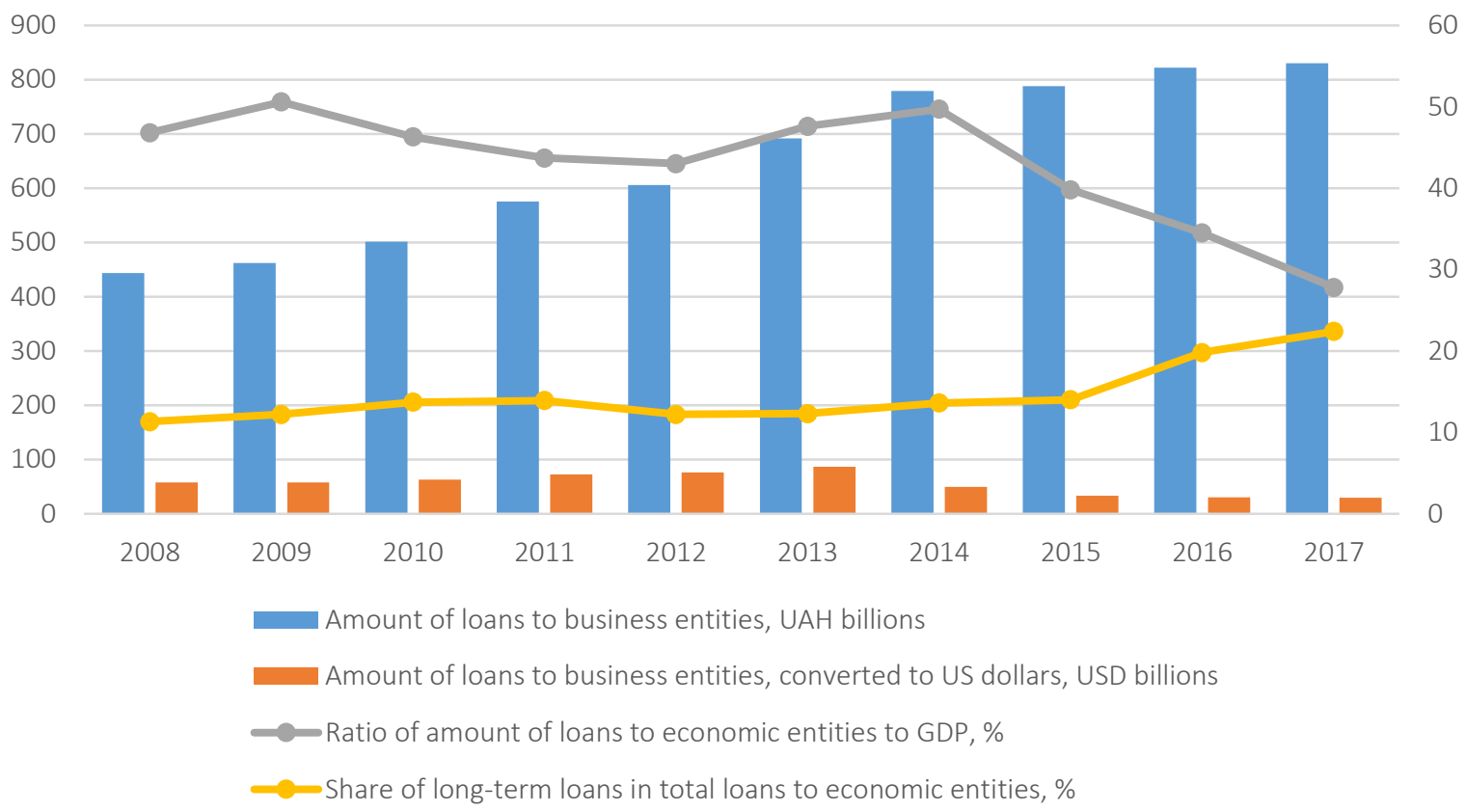

Figure 2. Some indicators on the base of lending activity of the Ukrainian banks in 2008-2017 
times, more than $90 \%$ of long-term (over two years or more) funds belongs to state-owned enterprises. However, the share of time deposits of business entities in the total amount of their bank funds decreased from $51 \%$ to $32 \%$, which indicates that now enterprises have relatively less temporarily available funds (National Bank of Ukraine, 2019b).

\subsection{Analysis of the impact of the banking system performance on the financial equilibrium of enterprises in Ukraine}

Table 1 presents a database for modeling the relationship between indicators of the performance of the banking system and the financial equilibrium of enterprises.

The given database is used to develop the multivariate regression using mathematical gnostic analysis in the program shell $R$ Console. $R$ is a programming language for statistical processing of data, combined with a mathematical analysis. The function GWLS (GWLS - gnostics of weighted least squares) was used to develop a model for forecasting the financial equilibrium of the enterprises. The following regression equation was obtained:
$Y=-0.01144 \cdot X_{1}+0.00083 \cdot X_{2}-$

$-0.04411 \cdot X_{3}-0.03711 \cdot X_{4}+0.10503 \cdot X_{5}-$

$-0.00362 \cdot X_{6}-0.02918 \cdot X_{7}+0.03744 \cdot X_{8}$.

Model (1) has an error of forecast of the effective index lower than the standard deviation of its actual value. This indicates the adequacy of the model (1) to predict the financial equilibrium index of enterprises. Appendix A presents the statistical characteristic of this model. Model (1) can be considered valid, since the null hypothesis is insolvent. This is evidenced by a low, less than 0.02 , probability of its existence.

The analysis of the model's coefficients allows to state inverse relationship between the amounts of bank lending to enterprises and their financial equilibrium. This is at variance with the economic role of lending in market economy: instead of stimulating the progress of the real economy in Ukraine, bank lending is hampering it. The reason for this is in the strict terms of lending, dictated by long-term economic instability with rising of risks in banking and the restrictive nature of monetary policy. Sensitive to a wide range of negative external factors, banks are trying only to save their business rather than to develop (Table 2).

Table 1. Database for analyzing the impact of the banking system on the financial equilibrium of enterprises in Ukraine in 2008-2017

\begin{tabular}{|c|c|c|c|c|c|c|c|c|c|c|}
\hline Indicators & 2008 & 2009 & 2010 & 2011 & 2012 & 2013 & 2014 & 2015 & 2016 & 2017 \\
\hline $\begin{array}{l}\text { Growth rate of loans granted by banks to economic } \\
\text { entities }\left(X_{1}\right), \%\end{array}$ & 170.3 & 104.2 & 108.4 & 114.9 & 105.2 & 114.3 & 112.6 & 101.1 & 104.4 & 101.0 \\
\hline $\begin{array}{l}\text { Growth rate of mortgage loans provided by banks to } \\
\text { households }\left(X_{2}\right), \%\end{array}$ & 278.3 & 120.1 & 278.0 & 104.5 & 109.9 & 140.8 & 117.0 & 81.2 & 277.6 & 142.1 \\
\hline $\begin{array}{l}\text { Average weighted annual interest rate on bank loans } \\
\text { granted to economic entities in national currency } \\
\left(X_{3}\right), \%\end{array}$ & 17.2 & 21.0 & 14.9 & 14.7 & 17.3 & 15.2 & 16.7 & 21.4 & 17.7 & 15.0 \\
\hline $\begin{array}{l}\text { Share of non-performing assets in the bank's loan } \\
\text { portfolio }\left(X_{4}\right), \%\end{array}$ & 2.3 & 9.4 & 11.2 & 9.6 & 8.9 & 7.7 & 13.5 & 22.1 & 25.3 & 54.5 \\
\hline $\begin{array}{l}\text { Share of time deposits of economic entities in the } \\
\text { amount of resources attracted by banks from this } \\
\text { category of clients }\left(X_{5}\right), \%\end{array}$ & 51.0 & 43.8 & 38.4 & 39.9 & 45.8 & 44.6 & 39.2 & 30.3 & 25.5 & 32.0 \\
\hline Average weighted discount rate $\left(X_{6}\right), \%$ & 10.7 & 11.2 & 8.7 & 7.8 & 7.5 & 7.0 & 10.2 & 25.5 & 17.8 & 13.2 \\
\hline $\begin{array}{l}\text { Ratio of value of DGLB** in banks' assets and long- } \\
\text { term loans granted to economic entities }\left(X_{7}\right) \text {, units }\end{array}$ & 0.2 & 0.8 & 1.3 & 1.2 & 1.2 & 1.1 & 1.3 & 0.9 & 1.4 & 4.1 \\
\hline Monetization of the economy $\left(X_{8}\right), \%$ & 54.4 & 53.4 & 55.4 & 52.7 & 55.0 & 62.0 & 61.1 & 50.2 & 46.3 & 40.5 \\
\hline Enterprise financial equilibrium index $(Y) * * *$ & 0.401 & 0.751 & 0.702 & 0.691 & 0.719 & 0.781 & 0.402 & 0.156 & 0.163 & 0.191 \\
\hline
\end{tabular}

Note: * calculated by the authors on the base of the National Bank of Ukraine (2019b) data. ** DGLB - Domestic Government Loan Bonds. *** calculated by the authors on the base of the methodology developed by Gudz (2018). 
Table 2. Correlation between the banks' capitalization and the monetary indicators in Ukraine in 2008-2017

Source: Developed by the authors on the base of the National Bank of Ukraine (2019b, 2019c) data.

\begin{tabular}{|c|c|c|c|c|c|c|c|c|c|c|c|}
\hline Indicators & 2008 & 2009 & 2010 & 2011 & 2012 & 2013 & 2014 & 2015 & 2016 & 2017 & $\begin{array}{c}\text { Correlation } \\
\text { index }\end{array}$ \\
\hline $\begin{array}{l}\text { Sufficiency (adequacy) of banks' } \\
\text { regulatory capital, } \%\end{array}$ & 14.01 & 18.08 & 20.83 & 18.9 & 18.06 & 18.26 & 15.6 & 12.74 & 12.69 & 16.1 & $x$ \\
\hline Inflation index, \% & 122.3 & 112.3 & 109.1 & 104.6 & 99.8 & 100.5 & 124.9 & 143.3 & 112.4 & 113.7 & -0.698 \\
\hline Devaluation rate, $\%$ & 52.5 & 3.7 & 1.8 & 0.4 & 0.3 & 0.03 & 32.8 & 45.5 & 14.5 & 3.9 & -0.747 \\
\hline $\begin{array}{l}\text { Discount rate (at the end of the } \\
\text { period), \% }\end{array}$ & 12.0 & 10.25 & 7.75 & 7.75 & 7.5 & 6.5 & 14.0 & 22.0 & 14.0 & 14.5 & -0.816 \\
\hline
\end{tabular}

The correlation indices in Table 2 indicate that the adequacy of regulatory capital of banks is under the significant pressure of three monetary factors: inflation, devaluation of the Ukrainian hryvnia, and discount rate. This means that neither market conditions nor monetary regulation contribute to the development of banking in Ukraine. In turn, the current financial position and the economic performance of domestic enterprises are not able to ensure the efficient use of the borrowed funds. At the same time, a persistent deficit of resources of economic entities requires the expansion of funding. Working capital shortage at enterprises of Ukraine has increased in 2008-2017 by eight times, in the industry - by eighteen times (State Statistics Service of Ukraine, 2019).

The current interest rate policy of banks is a result of the monetary policy of "expensive money". The operating profitability of the real sector in 2017 was $8.8 \%$ on average, in particular in industry 6.8\% (State Statistics Service of Ukraine, 2019). The profitability of the core activity of enterprises, which is lower than the interest rate, is not able to ensure them a positive effect of the financial leverage in the form of the growth of own capital due to the activation of the internal source of its formation - net profit. However, expensive bank loans are only an intermediate element of the negative impact of monetary policy on the financial equilibrium of enterprises. Its origins are in the discount policy of the NBU. A negative effect of the discount rate should be noted not only on the financial stability of the banking system, but also on the index of financial equilibrium of enterprises. According to model (1), each percentage point increase in the discount rate leads to a decrease in the index of financial equilibrium by 0.00362 units.
Restrictive monetary policy deforms the socio-economic role of banks; the reallocation of funds from the real sector of the economy to the banking sector takes place. By rising the discount rate, the central bank stimulates the profitability of bank assets through transferring to a borrower not only the risk of non-returning of his own loan, but the other ones as well. It is much more important to increase the turnover of bank assets, but the solvency of enterprises should be increased for this to happen. However, the latter now is twice lower than the optimal level with a tendency to decrease over the last decade (State Statistics Service of Ukraine, 2019). In Ukraine, the share of problem bank loans in their total portfolio for 20082017 has grown twenty-four times. At the beginning of 2019, the loan portfolio of banks has more than a half of non-performing assets (National Bank of Ukraine, 2019c). According to model (1), the increase in the share of non-performing assets in the loan portfolio of banks by 1 p.p. leads to a decrease in the index of financial equilibrium of enterprises by 0.03711 units on average.

Not being used efficiently in the real sector, banks' funds are directed to servicing the government budget deficit. Over the past ten years, the amount of DGLBs in bank assets has grown sixty-four times with state-owned banks as the main buyers of the bonds and the latter's share in their assets amounting to $30 \%$ (National Bank of Ukraine, 2019c). In 2017, the amount of banks' investment in government debt securities exceeded the amount of long-term loans granted to economic entities by four times. With each increase of this ratio per unit, the financial equilibrium index of enterprises is reduced by an average of 0.02918 units. Investing banks' funds into liquid and profitable government securities is explained by the fact that, on the one hand, DGLBs are refinanced 
by the NBU, and, on the other hand, financial capital always searches the most profitable spheres of investment.

An increase in the financial resources of the economy contributes to the greater diversification of the demand for money, strengthening the investment capacity of cash flows for the growth of the real sector, as well as creation of financial grounds to prevent artificial shortage of payment means. However, economic environment in Ukraine is characterized by the opposite processes. The monetization of the Ukrainian economy in 2017 has reached the lowest rate for the last ten years $-40.53 \%$. For comparison, in the OECD countries this indicator is $117 \%$, in China $-200 \%$, while in Ukraine it has fallen to the limit typical for the developing countries (40-60\%) (World Bank, 2017). This indicates an aggravation of the problem of artificial shortage of money, which hampers the investments in the economy. As model (1) shows, the growth of the monetization of the economy by 1 p.p. contributes to the increase of the index of financial equilibrium of enterprises by 0.03744 units. It is important to note that this factor is an incentive for the formation of the highest level of financial equilibrium of enterprises, which reflects their capacity to progressive development.
Mortgage lending is one of the internal financial incentives for national economic development. In Ukraine, mortgage loans provided to households have had unstable dynamics in 2008-2017 (Table 1). However, their positive impact on the financial equilibrium of enterprises is characterized by model (1): with an increase in the growth rate of mortgage loans by 1 p.p., the index of financial equilibrium of enterprises increases by an average of 0.00083 units. This interaction is realized through a system of economic interconnections between different branches of the economy. Housing construction expands demand, first of all, for industrial goods. In turn, it stimulates the development of transport, trade, services, and also creates new jobs. The development of mortgage lending is a catalyst for the progress of the economy as a whole, but in the situation of increase in domestic production rather than import. The high import dependence of Ukraine by most groups of manufactured products reduces the positive effect of bank mortgage lending.

The closer the partnership of business entities with banks is, the greater is the economic effect of synergy. It is indicated by the deposit services. Efficient financial management performs balancing liquidity and profitability at an acceptable level of risk. Time deposits are one of the tools for

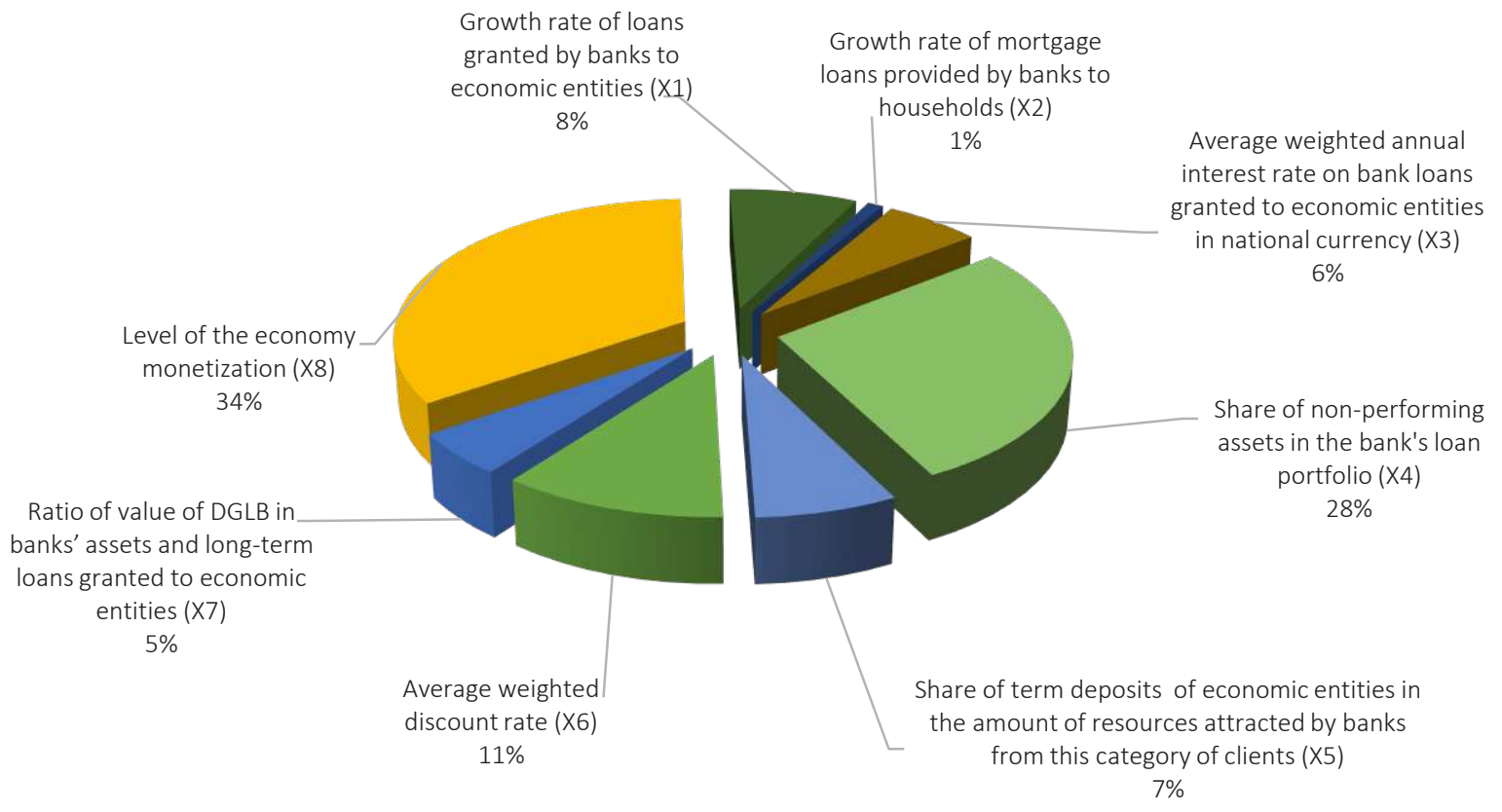

Figure 3. Role of bank performance indicators in the forecasting the index of financial equilibrium of enterprises in Ukraine in the medium term 


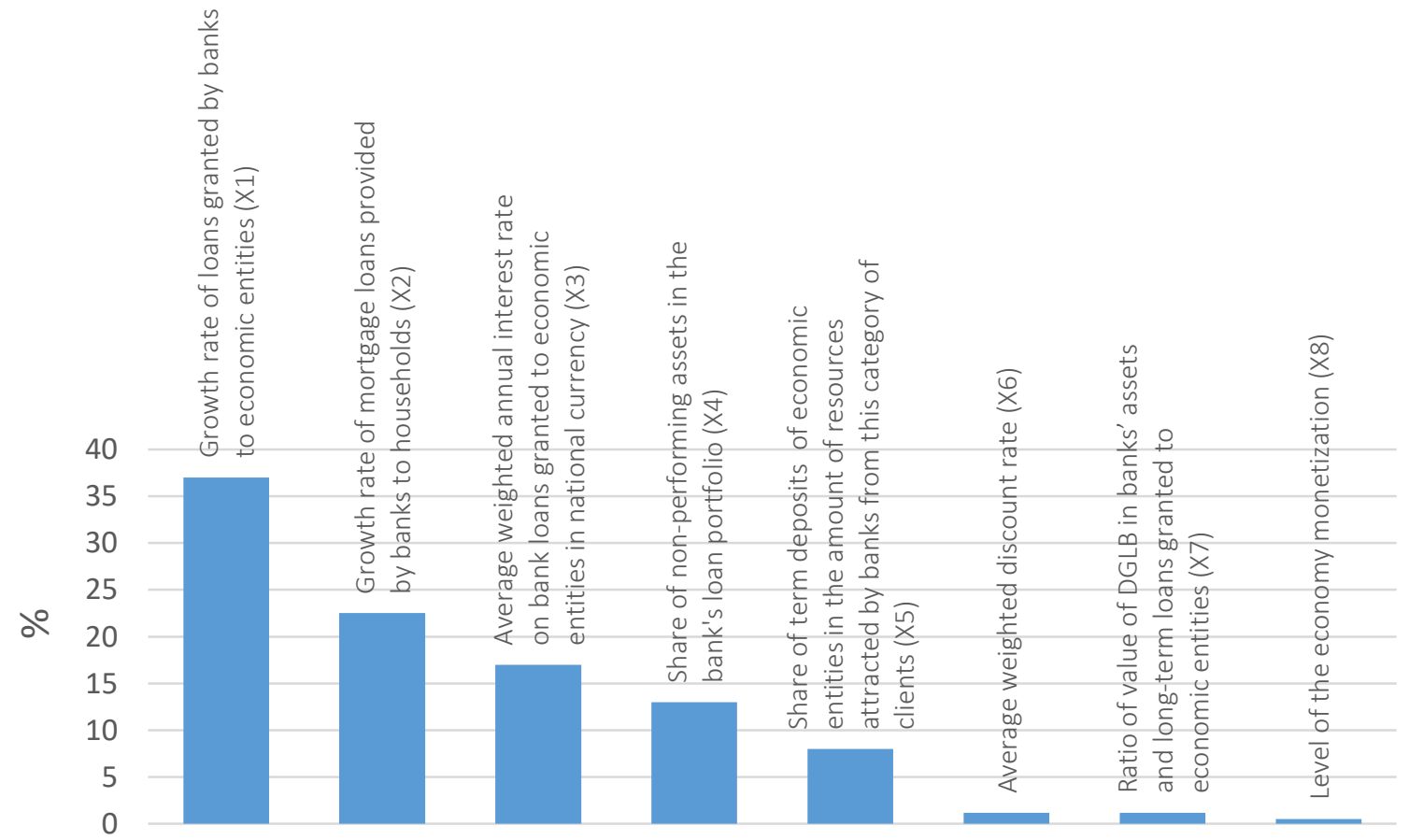

Figure 4. Priority ranking of bank performance indicators influence on the forecast index of financial equilibrium of enterprises in Ukraine in the short term

solving this financial collision. As model (1) shows, with the growth of the share of time deposits of business entities by 1 pp., the index of their financial equilibrium increases by 0.10503 units. The available liquidity of enterprises is effectively used through the banking sector in the economic sectors needed growth.

The processing of the raw data in the $\mathrm{R}$ Console software program allowed to explore the role of banking performance indicators in the forecasting the index of financial equilibrium of enterprises in the medium-term (Figure 3) and the shortterm (Figure 4) prospects.

The monetization of the economy, the share of non-performance assets in the loan portfolio of banks and the discount rate are crucial for the financial equilibrium of enterprises in the threeyear perspective. This means that the priority in the medium-term period is given to the factors that have general economic nature and are equally important both for banks and enterprises.

It is interesting to compare the change of these priorities in the short-term period (Figure 4). The providing of bank loans on affordable terms ranks first. This means that currently it is important for financial management of enterprises to ensure the balance of cash flows, payment requirements and obligations.

Another feature of the short-term financial equilibrium is that the use of monetary instruments has a postponed effect. That is why, the role of the discount rate in ensuring the short-term financial equilibrium of enterprises is minimized. Similarly, the growth rate of mortgage lending stimulates the development of the economic sectors in the long run. So, in the current period, the mutual influence of the financial positions of banks and enterprises is most pronounced. There is a cross-sectoral interaction between the banking and the real sector of the economy. Quantitative growth ensuring the stability of banks and the financial equilibrium of enterprises stimulates a qualitative transformation of the environment for their performance.

The results of the forecast based on model (1) show that in the next two years, while preserving the existing direction of monetary and economic policy, there is no ground to expect the significant increase in the index of enterprises' financial equilibrium (Figure 5). 


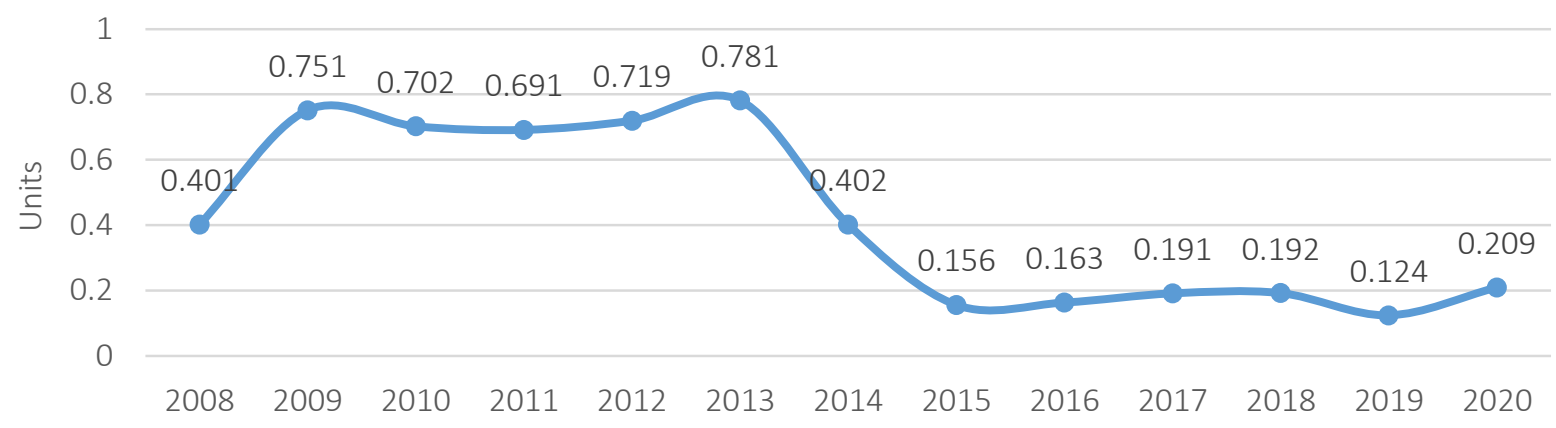

Figure 5. Forecast of the index of Ukrainian enterprises' financial equilibrium for 2019-2020

It is obvious that the banking system, which is compelled to combat for its financial stability, cannot in fact be the source of funds for innovative transformations in the real sector of economy. Besides, by providing their financial services, the banks cannot stop the processes of deindustrialization of the Ukrainian economy characterized by a decline in the share of industrial production in GDP, technological decline, lack of innovation, etc. The interaction of monetary and economic policy is required aiming at creation of effective mechanisms for innovation development of enterprises with the participation of banks as financial intermediaries.

\section{CONCLUSION}

The theory and practice of interaction between the banking and the real sectors of the economy in Ukraine are somewhat different. It results, first of all, from the negative impact of bank lending on the financial equilibrium of enterprises. The banking system is not able to provide the economic entities with affordable funds because of the incorrectly set priorities of government economic regulation. Assets of Ukrainian enterprises are seven times higher than financial resources of banks. Therefore, the basis for development should be laid by economic policy, while monetary policy has to take adequate compensative and stimulating measures. In Ukraine, the situation is quite opposite.

The banking and the real sectors of the economy have a common problem - violation of capital accumulation process. The financial capacity of both of them is exhausting that is confirmed by the decreased monetization of the Ukrainian economy. Therefore, it is not a question of growth today, but of the renewal of the socio-economic role of banks. This requires reducing the outflow of capital from the country through the channels of import of goods and export of national economy revenues. Enterprises need long-term investment through replenishment of their own capital rather than increase in liabilities, because the half of the banks' loans to economic entities is now the bad ones.

There is a conflict of financial opportunities. Enterprises cannot be effective recipients of bank loans; in turn, banks cannot take higher financial risks. The solution to the problem is in the sphere of development and implementation of the government economic policy, whose main task has to be innovation development of domestic production.

The role of the banking system in realization of these pathways may be enhanced by the implementation of a loyal refinancing regime for banks that heavily grant investment loans. The liquidity of such banks will be increased. It is worth adding fiscal incentives, for instance, an exemption of the interest income on issued investment loans from taxation. This will enhance the financial interest of banks to expand investment lending. Exemption of interest income on long-term deposits from taxation will contribute to the formation of long-term liabilities of banks. At the same time, the use of fiscal instruments to limit 
the growth of speculative financial transactions of banks will stimulate their interest in lending. This will facilitate the transformation of the banks' performance according to the concept of "relationship banking". The implementing of an innovative banking service in Ukraine such as project financing could be an effective tool in this case.

\section{REFERENCES}

1. Altman, I. E., \& La Fleur, K. J. (1981). Managing a return to financial health. The Journal of Business Strategy, 2(1), 31-38. https:// doi.org/10.1108/eb038922

2. Belolipetskiy, V. G. (2000). Финансовое равновесие в национальном хозяйстве [Finansovoye ravnovesiye $v$ natsionalnom khoziaystve]. Moscow: TEIS.

3. Bernanke, B., \& Gertler, M. (1985). Banking in general equilibrium (NBER Working Paper No. 1647). Retrieved from https://www.nber. org/papers/w1647

4. Besanko, D., \& Thakor, A. V. (1993). Relationship Banking, Deposit Insurance, and Bank Portfolio Choice. In C. Mayer \& X. Vives (Eds.), Capital Markets and Financial Intermediation (292-319). Cambridge: Cambridge University Press.

5. Bilenko, Yu. I. (2015). Роль розвитку банківських систем у фінансуванні основного капіталу підприємств у країнах Центральної та Східної Європи [Rol rozvytku bankivskykh system u finansuvanni osnovnoho kapitalu pidpryiemstv u krainakh Tsentralnoi ta Skhidnoi Yevropy]. Visnyk Odeskoho natsionalnoho universytetu imeni I. I. Mechnikova, 20(4), 22-26. Retrieved from http://nbuv.gov.ua/UJRN/Vonu_ econ_2015_20_4_6

6. Bolton, P., \& Freixas, X. (2006). Corporate finance and the monetary transmission mechanism. The Review of Financial Studies, 19(3), 829-870. https://doi.org/10.1093/ rfs/hhlo02

7. Boot, A. W. A. (2000). Relationship banking: what do we know? Journal of Financial Intermediation, 9(1), 7-25. https://doi.org/10.1006/ jfin. 2000.0282

8. Davis, E. P. (1994). Banking, corporate finance, and monetary policy: an empirical perspective. Oxford Review of Economic Policy, 10(4), 49-67. Retrieved from https://www.jstor.org/stable/23606344

9. Dhaliwala, D. S., Li, O. Z., \& Xie, H. (2010). Institutional investors, financial health, and equity valuation. Asia-Pacific Journal of Accounting \& Economics, 17(2), 151-173. https://doi.org/10.1080/1 6081625.2010.9720858

10. Gudz, T. P. (2018). Теорія i методологія формування фінансової рівноваги підприємства [Teoriia i metodolohiia formuvannia finansovoi rivnovahy pidpryiemstva]. Poltava: PUET.

11. Kostyrko, L. A. (2008). Діагностика потенціалу фінансово-економічної стійкості підприємства [Diahnostyka potentsialu finansovoekonomichnoi stiikosti pidpryiemstva]. Kharkiv: Factor.

12. Kovalenko, V. V. (2013). Фінансово-кредитна взаємодія банків і підприємств [Finansovokredytna vzaiemodiia bankiv i pidpryiemstv]. Efektyvna ekonomika, 4. Retrieved from http://www.economy.nayka.com. ua/?op $=1 \& z=1918$

13. Law, J. (2018). A Dictionary of Finance and Banking. Oxford: Oxford University Press.

14. Lvova, N. (2019). Corporate financial health assessment: methods and tools for emerging markets. Ekonomika i banki, 1, 23-29. Retrieved from http://ojs.polessu.by/ $\mathrm{EB} /$ article/view/1234/1041

15. Malyarets, L., Dorokhov, O., Koybichuk, V., \& Dorokhova L. (2019). Obtaining a Generalized Index of Bank Competitiveness Using a Fuzzy Approach. Journal of Central Banking Theory and
Practice, 8(1), 163-182. Retrieved from https://www.cbcg.me/repec/ cbk/journl/vol8no1-8.pdf

16. National Bank of Ukraine. (2019а). Аналіз діяльності CEП [Analiz diialnosti SEP]. Retrieved from https://bank.gov. ua/control/uk/publish/article?art_ id $=62840838 \&$ cat_id $=62840843$

17. National bank of Ukraine (2019b). Грошово-кредитна та фінансова статистика [Groshovo-credytna ta finansova statystyka]. Retrieved from https://bank.gov.ua/control/uk/ publish/article?art_id=69009\&cat_ $\mathrm{id}=58127$

18. National Bank of Ukraine. (2019c). Показники банківської системи [Pokaznyky bankivskoi systemy]. Retrieved from https://bank.gov. ua/control/uk/publish/article?art_ id $=34661442 \&$ cat_id=34798593

19. Niezviestnaia, O. V. (2016). Дослідження сучасного стану та інструментів фінансової підтримки підприємств з боку банківського сектору [Doslidzhennia suchasnoho stanu ta insrumentiv finansovoi pidtrymky pidpryiemstv $\mathrm{z}$ boku bankivskoho sektoru]. Tekhnologicheskiy audit i reservy proizvodstva, 4/5, 32-36. Retrieved from http://nbuv.gov.ua/ UJRN/Tatrv_2016_4\%285\%29_7

20. Savchenko, Т. Н. (2011). Структура механізму впливу банківської системи на рівноважні стани у економіці [Struktura mekhanizmu vplyvu bankivskoi systemy na rivnovazhni stany u ekonomitsi]. Ekonomika i rehion, 4, 53-58. Retrieved from http://nbuv.gov.ua/ UJRN/econrig_2011_4_13

21. Schnitzer, M. (1999). On the role of bank competition for corporate finance and corporate control in transition economies. Journal of Institutional and Theoretical Economics, 
155(1), 22-46. Retrieved from http:// www.jstor.org/stable/40752119

22. State Statistics Service of Ukraine. (2019). Економічна статистика. Економічна діяльність.

Діяльність підприємств [Есоnomichna statystyka. Ekonomichna diialnist. Diialnist pidpryiemstv]. Retrieved from http://www. ukrstat.gov.ua

23. Sufi, A. (2005). The role of banks in corporate finance. Massachusetts Institute of Technology Digital
Dissertations. Retrieved from https://dspace.mit.edu/handle/1721.1/32397

24. The World Bank. Data. (2015). Broad money (\% of GDP). Retrieved from https://data.worldbank. org/indicator/FM.LBL.BMNY. GD.ZS?view=chart

25. Yehorycheva, S. B. (2012)

Стратегії інноваційної діяльності комериійних банків [Stratehii innovatsiinoi diialnosti komertsiinyh bankiv]. Electronic archive of Poltava University of Economics and Trade. Retrieved from http://dspace.puet.edu.ua/ handle/123456789/4408

26. Yehorycheva, S., Kolodiziev, O., \& Prasolova, S. (2017). Actual Problems of the Ukraine's Banking System Capital Stability Management. Banks and Bank Systems, 12(2), 60-67. http://dx.doi.org/10.21511/ bbs.12(2).2017.06

\section{APPENDIX A}

Table A1. Statistical characteristic of the model forecasting the financial equilibrium index of Ukrainian enterprises influenced by the banking system

\begin{tabular}{|c|c|c|c|c|c|}
\hline Factors & Coeffs. & $\begin{array}{c}\text { Std } \\
(C[k])\end{array}$ & Mean $(x[, k])$ & $\begin{array}{l}\text { Mean } \\
(C x[, k]) \\
\end{array}$ & $\begin{array}{c}\text { Probability } \\
\text { value }\end{array}$ \\
\hline $\begin{array}{l}\text { Growth rate of loans granted by banks to economic } \\
\text { entities }\left(X_{1}\right), \%\end{array}$ & -0.01144 & 0.012 & 108.700 & 0.062 & 0.010 \\
\hline $\begin{array}{l}\text { Growth rate of mortgage loans provided by banks } \\
\text { to households }\left(X_{2}\right), \%\end{array}$ & 0.00083 & 0.132 & 158.432 & 0.069 & 0.006 \\
\hline $\begin{array}{l}\text { Average weighted annual interest rate on bank } \\
\text { loans granted to economic entities in national } \\
\text { currency }\left(X_{3}\right), \%\end{array}$ & -0.04411 & 0.074 & 16.843 & 0.103 & 0.0001 \\
\hline $\begin{array}{l}\text { Share of non-performing assets in the bank's loan } \\
\text { portfolio }\left(X_{4}\right), \%\end{array}$ & -0.03711 & 0.521 & 14.043 & 0.256 & 0.003 \\
\hline $\begin{array}{l}\text { Share of term deposits of economic entities in the } \\
\text { amount of resources attracted by banks from this } \\
\text { category of clients }\left(X_{5}\right), \%\end{array}$ & 0.10503 & 0.095 & 37.671 & 0.772 & 0.017 \\
\hline Average weighted discount rate $\left(X_{6}\right), \%$ & -0.00362 & 0.044 & 12.071 & 0.025 & 0.019 \\
\hline $\begin{array}{l}\text { Ratio of value of DGLB in banks' assets and long- } \\
\text { term loans granted to economic entities }\left(X_{7}\right) \text {, units }\end{array}$ & -0.02918 & 0.035 & 1.200 & 0.005 & 0.0002 \\
\hline Monetization of the economy $\left(X_{8}\right), \%$ & 0.03744 & 0.047 & 54.671 & 0.210 & 0.004 \\
\hline
\end{tabular}

